\title{
Fabrication and Performance of Laterite East Kotawaringin-Zeolite/Chitosan Composite as Slow Release of Iron Fertilizer
}

\author{
Rendy Muhamad Iqbal ${ }^{1 *}$, Sri Wardhani ${ }^{2}$, Darjito ${ }^{2}$, Karelius ${ }^{1}$ \\ ${ }^{1}$ Department of Chemistry, Faculty of Science, University of Palangka Raya, Palangka Raya, Indonesia \\ ${ }^{2}$ Department of Chemistry, Faculty of Mathematics and Natural Science, \\ Brawijaya University, Malang, Indonesia \\ *email: rendiqbale@gmail.com
}

Received September 16; 2018; Accepted November 29; 2018; Available online December 8, 2018

\begin{abstract}
Laterite soil is one of natural resources in East Kotawaringin regency, Central Kalimantan, Indonesia, which contains high element of $\mathrm{Fe}$. $\mathrm{Fe}$ is one of micronutrients that is needed for plant in slight amount. This study aims to determine the effect of chitosan composition and composition of zeolite : laterite on the release of Fe activities from synthesized fertilizers result. Laterite is characterized by using XRF and XRD. Slow release iron fertilizer is synthesized by eliciting laterite to zeolite matrix. Then, It is stirred into chitosan gel with concentration of 2, 2.6, and $2.8 \%$ for 30 minutes. After Zeolite - laterite - chitosan has been homogenized, then it is dropped into $0.4 \mathrm{M} \mathrm{NaOH}$ to form beads. Then testing the release of $\mathrm{Fe}$ with the batch method in distilled water. The result showed that the laterite soil is amorphous form, and Fe content reached $80.25 \%$. The higher the concentration of chitosan which is used, then more Fe is released from fertilizer. Whereas if the amount of zeolite is greater, the slower the release of $\mathrm{Fe}$ will be.
\end{abstract}

Keywords: laterite, slow release, zeolite, chitosan, composite

\section{INTRODUCTION}

The formation of mineral by nature obtained many type of rocks such as metamorph, bauxite, sediment, pyroclastic, and laterite. Many places in Indonesia that the soil contained laterite mineral and Indonesia was the second largest country which has laterite content in those soil. Primary compound of laterite was iron, aluminium, and silica (Prasetiyo, 2008). The highest amount of iron in laterite could utilize to fulfilled micronutrients for plants. As micronutrient, iron has function as catalyst for synthesis of chlorophyll and helping transport system. The amount of iron which needed by plants was $100 \mathrm{mg} / \mathrm{L}$ (ppm) per day, but it's depend on type and age of their.

Some case about iron deficiency was found in many places in Indonesia such as Sulawesi and Nusa Tenggara. If the supply of iron was not good enough for the plant, it caused chlorosis disease, while if the plants have excess of iron nutrition that it will caused toxic. So that required effective way to meet the needs of the plant with a slow release system. The advantages fertilizer with slow release system were releasing of nutrient can be controlled and the lifetime of fertilizer will be longer (Kottegoda, Munaweera, Madusanka, \& Karunaratne, 2011; Yao, Gao,
Chen, \& Yang, 2013). Kottegoda et al. reported that the use of hydroxyapatite as material to controlled of micronutrient releasing (Kottegoda et al., 2011), Azeem et al reported that the some technique based sulfur, polymer, superabsorbent/water retention, and bio-composite based coating materials (Azeem, Kushaari, Man, Basit, \& Thanh, 2014).

Another promising way to fabricated material for slow release fertilizer by impregnated micronutrient into porous materials such as aluminosilicate, bentonite (Piluharto, Suendo, \& Maulida, 2017), montmorillonite, and zeolite (Cairo et al., 2017). Zeolite is attractive porous material that has good regularity of the pores and good mechanical as well as thermal stability (Hartanto et al., 2017). After impregnation process, it can be continued by phase inversion-immersion precipitation to casting the fertilizer and combining micronutrientporous material with polymer binder to form composite which has similar principle with membrane fabrication (Iqbal, Nurherdiana, Hartanto, Othman, \& Fansuri, 2018). The advantages of this process were the casting would be easily, porous of composite can be designed by the choice of solvent-nonsolvent, then micronutrient release can be slower due to combination with polymer binder. Polymer 
binder also has function as encapsulation and it's very good to controlled amount of micronutrient releasing (Rashidzadeh, Olad, Salari, \& Reyhanitabar, 2014).

Some type polymer as well as biopolymer can be used to controlled amount of micronutrient release such as alginate, polysulfone, chitin, and chitosan. Chitosan is very famous biopolymer which is used by many researchers in the world for many applications, because it's very easy to isolated from animal-like shrimp shells (Phuc et al., 2016).

In this paper will explain our effort to utilize laterite soil from East Kotawaringin as source of iron which is combined with natural zeolite and chitosan to fabricated slow-release material.

\section{EXPERIMENTAL SECTION}

\section{Chemical and Instrumentation}

The materials are laterite soil from East Kotawaringin, natural zeolite from Turen, chitosan, $\mathrm{NaOH}$, acetic acid, $\mathrm{NH}_{4} \mathrm{SCN}, \mathrm{HCl}$, and $\mathrm{HNO}_{3}$. Instrumentation that used in this research such as FTIR spectrophotometer (Shimadzu FTIR QP89500, sample was analyzed using $\mathrm{KBr}$ plate), XRD, XRF Panalytical MiniPAL 4, and spectrophotometer UV-Vis.

\section{Pretreatment of laterite soil and natural zeolite}

Laterite soil washed with aquades and drying into oven at $110{ }^{\circ} \mathrm{C}$ for $2 \mathrm{~h}$. Then, it grinded until forming softer powder and sieving using particular siever ( microns). After that, the powder of laterite soil calcined at $500{ }^{\circ} \mathrm{C}$ for $5 \mathrm{~h}$. Laterite characterized by XRD and XRF. For zeolite pretreatment, the first step is zeolite activation. Natural zeolite washed with aquades and drying into the oven at $110{ }^{\circ} \mathrm{C}$ for $2 \mathrm{~h}$. Then, it immersion into $\mathrm{HCl} 0.4 \mathrm{M}$ and stirred for 15 minutes. After that, filtrate and residue separated by filtration and residue washed with aquades until the $\mathrm{pH}=7$. The last step, zeolite calcined at $500{ }^{\circ} \mathrm{C}$ for $5 \mathrm{~h}$. The zeolite that used in this works was taken from Turen, and Difractogram of zeolite has been reported by Wardhani, Rahman, Purwonugroho, \& Tjahjanto (2016).

\section{Fabrication of Laterite East Kotawaringin-} Zeolite/Chitosan Composite

The first step of composite fabrication was impregnated laterite into zeolite by mixing them into methanol and it stirred for 5 h. Then laterite-zeolite calcined at $500{ }^{\circ} \mathrm{C}$ for $5 \mathrm{~h}$, then laterite-zeolite calcined and uncalcined used to fabricated the composite. $10 \mathrm{~g}$ of calcined and uncalcined lateritezeolite mixed with chitosan gel $2 \%$ and stirred them for 30 minutes (to form dope solution). After that, the dope solution was cast to form beads and immersion them into $\mathrm{NaOH} 0.4 \mathrm{M}$. Chitosan gel made by mixing chitosan powder with acetic acid $1 \%$.

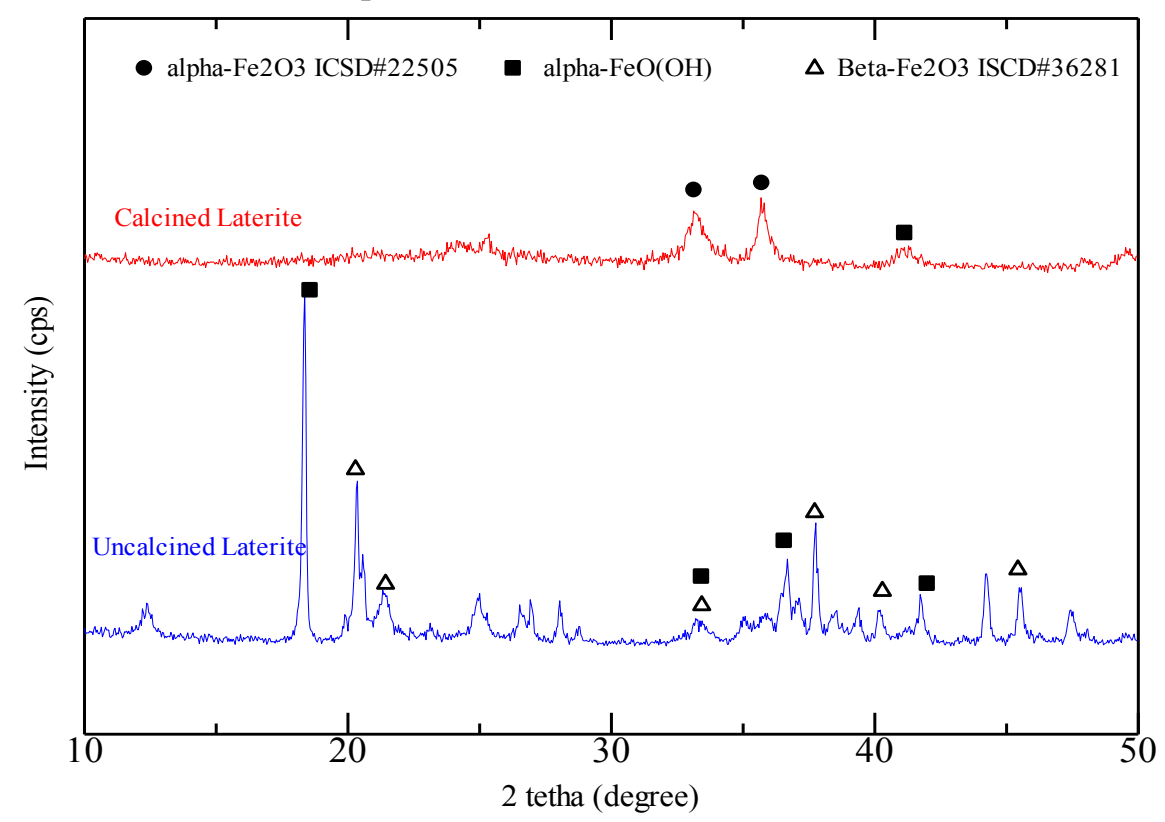

Figure 1. XRD pattern of laterite soil from East Kotawaringin 
The second optimation in this study is the effect of chitosan concentration, similar to the above procedure. The calcined lateritezeolite mixed into chitosan gel with different concentration $(2,2.6$, and $2.8 \%)$, then it cast to form beads. The third optimation is the effect of zeolite and laterite ratio, the dope solution was made by mixing laterite-zeolite with different ratio $2: 1,1: 1$, and $1: 2$ into chitosan gel $2 \%$. The casting process was similar with the above procedure. The composite characterized by FTIR.

Fe release of each composite was tested by immersion of $3 \mathrm{~g}$ composite into aquades $100 \mathrm{~mL}$ for 5 days. Every $24 \mathrm{~h}$, the sample was measured by spectrophotometer UV-Vis using $\mathrm{NH}_{4} \mathrm{SCN}$ as a complexing agent at 461 $\mathrm{nm}$.

\section{RESULTS AND DISCUSSION}

\section{Characterization of Laterite soil from East Kotawaringin}

Laterite is characterized using $\mathrm{X}$-ray Fluorescence (XRF), XRF result represents the highest compound of laterite East Kotawaringin is iron (Table 1). It was wellknown that the main compound of laterite is iron, but the percentage of iron from one place and another place was different. It influenced by geographical activity in their place.

Table 1. XRF result of laterite soil from East Kotawaringin

\begin{tabular}{cc}
\hline Compound & Percentage $(\%)$ \\
\hline $\mathrm{Fe}$ & 80.25 \\
$\mathrm{Al}$ & 6.6 \\
$\mathrm{Si}$ & 5.4 \\
$\mathrm{Ti}$ & 2.88 \\
$\mathrm{Ni}$ & 2.13 \\
\hline
\end{tabular}

Laterite also characterized by X-Ray Diffraction (XRD) to determine crystal structure. As can be seen in Figure 1, XRD pattern of laterite represent that it was the mixture of goethite $(\alpha-\mathrm{FeOOH}$ JCPDS PDF No. 29-0713) and hematite (ICSD No. 22505 and 36281), the different structure in one material was formed by the natural process. But, the percentage of goethite and hematite into laterite can determine by comparing the intensity of specific peak. In addition, the calcined process of laterite was damaged crystal structure which is exhibited by XRD pattern after the calcining process. Some peaks of hematite and goethite were not appear which indicated the crystal structure of hematite and goethite was broke due to high temperature (Jozwiak, Kaczmarek, Maniecki, Ignaczak, \& Maniukiewicz, 2007; Mandal \& Axel, 2008). - $\mathrm{OH}$ from goethite was lose from the structure and it leads to amorphous formation.

The crystalline phase of laterite was change to be an amorphous phase after calcining, but some peak still appears in diffractogram. It might be caused the crystal structure can't break completely at $500{ }^{\circ} \mathrm{C}$, the higher temperature was possible to change completely from crystaline to amorphous phase. The advantages using amorphous phase for slow release fertilizer was iron will easily to release and the rate of release can be controlled using polymer binder and porous support material such as chitosan and natural zeolite that using in this work.

\section{FTIR Characterization}

The functional group that containing into laterite, zeolite, chitosan, and composite was determined by FTIR. The result was shown in Figure 2, the broad peak on 3300$3600 \mathrm{~cm}^{-1}$ caused overlapping of $-\mathrm{OH}$ and $\mathrm{NH}_{2}$ vibration for chitosan and composite spectrum. For zeolite and zeolite-laterite spectrum also appear $-\mathrm{OH}$ vibration which indicated $-\mathrm{OH}$ from $\alpha-\mathrm{FeOOH}$ and zeolite clinoptilolite-mordenite structure. The wavenumber around $2900 \mathrm{~cm}^{-1}$ exhibit $\mathrm{CH} \mathrm{sp}{ }^{3}$ from the composite structure. Then, at 1600$1750 \mathrm{~cm}^{-1}$ represent $-\mathrm{OH}$ bending from zeolite and composite, in those wavenumbers also exhibit $\mathrm{C}=\mathrm{O}$ and $\mathrm{C}-\mathrm{C}$ aromatic from chitosan spectrum. Based peak from the fingerprint area, there appear T-O-T and Fe-O which is from the vibration of zeolite and zeolitelaterite.

As can be seen from Table 2, calcining process of zeolite-laterite influenced on the intensity of their functional groups. Decreasing of intensity exhibit the bonding of functional groups of zeolite-laterite was stronger, so the vibration of zeolite-laterite molecules was more difficult to vibrating when contacted with an infrared beam. For composite spectrum appear of $-\mathrm{NH}_{2}$ stretching, $\mathrm{C}-\mathrm{H} \mathrm{sp}{ }^{3}$, -OH bending, $\mathrm{Fe}-\mathrm{O}$ which indicated functional groups of the raw material composite, it can be concluded that composite zeolite-laterite/chitosan was successfully synthesized. 


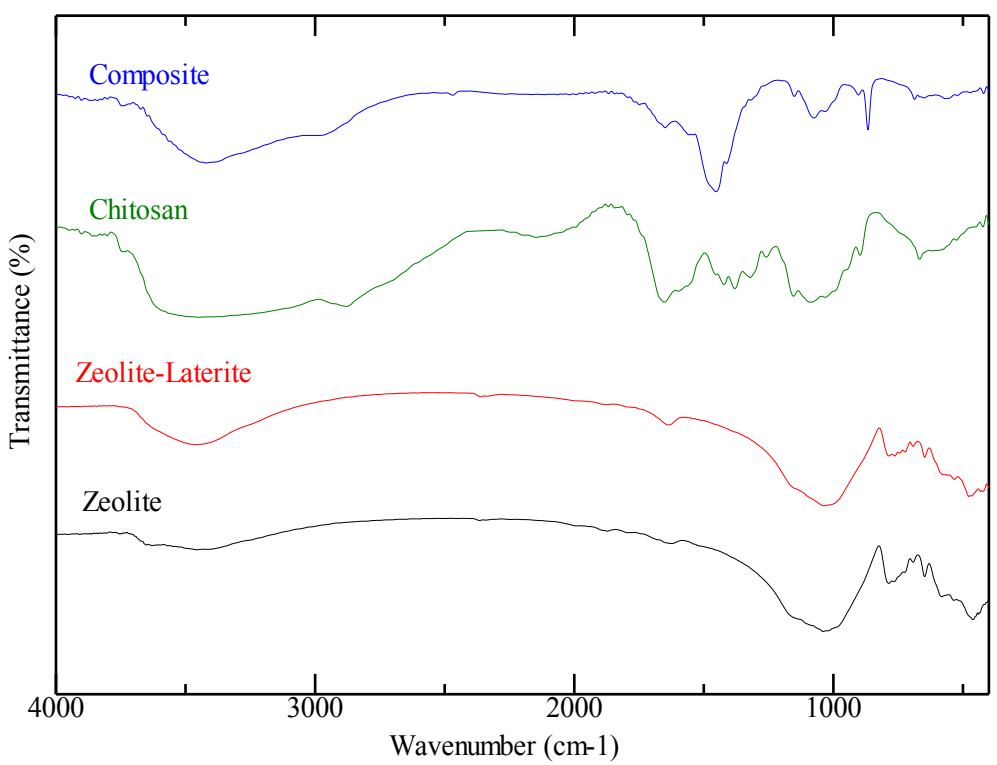

Figure 2. FTIR spectrum of zeolite, zeolite-laterite, chitosan, and composite

Table 2. Interpretation of FTIR Spectrum

\begin{tabular}{ccccc}
\hline Functional Group & $\begin{array}{c}\text { Zeolite } \\
\left(\mathrm{cm}^{-1}\right)\end{array}$ & $\begin{array}{c}\text { Chitosan } \\
\left(\mathrm{cm}^{-1}\right)\end{array}$ & $\begin{array}{c}\text { Zeolite-Laterite } \\
\left(\mathrm{cm}^{-1}\right)\end{array}$ & $\begin{array}{c}\text { Composite } \\
\left(\mathrm{cm}^{-1}\right)\end{array}$ \\
\hline $\mathrm{OH}$ & 3652.93 & 3363.62 & 3438.84 & \\
$\mathrm{NH}_{2}$ & - & 3363.62 & - & 3450.71 \\
$\mathrm{C}-\mathrm{H} \mathrm{sp}$ & - & 2881.45 & - & 2991.39 \\
$\mathrm{C}=\mathrm{O}$ & - & 1650.02 & - & - \\
$\mathrm{Si}-\mathrm{OH}$ & 1627.81 & - & 1627.81 & 1649.02 \\
Bending & & & & - \\
$\mathrm{C}-\mathrm{C}$ & - & 1596.95 & - & 1052.70 \\
Aromatic & & & & \\
T-O-T & 1083.92 & - & 1083.92 & - \\
T-O-T & 1024.13 & & 1024.13 & - \\
Fe-O & 784.97 & - & & - \\
\hline
\end{tabular}

Performance test of laterite East Kotawaringin-Zeolite/Chitosan Composite

Performance test of slow release of iron from composite beads using batch methods, and everyday the sample was measured using spectrophotometer $\mathrm{UV}-\mathrm{Vis}$ and $\mathrm{NH}_{4} \mathrm{SCN}$ as a complexing agent. Figure 3 showed the image of laterite soil and composite. The first parameter which tested in this works is the effect of zeolite-laterite calcination on release performance. Uncalcined zeolite-laterite (UZL) has the faster release if compared with calcined zeolite-laterite (CZL), it was shown by the higher amount of $\mathrm{Fe}$ which measuring. The increasing release of iron for UZL significantly increased from second to the third day, while for CZL was constantly increased from start tested until the fifth day. This data showed that releasing iron from composite has similar amount of each day, it was influenced by the bonding strength of CZL, because calcined process made the physical bonding will be stronger (Koinuma \& Takeuchi, 2004). The release performance of UZL and CZL is shown in Figure 4.

For UZL, increasing amount of iron at third day might due to swelling of the composite, at those time molecule of water diffuse into the composite and interacted with laterite which contains iron. In addition, chitosan has hydrophilic properties which make easily water to diffuse into the composite. Interaction of water and laterite made iron dissolved into water and releasing iron from the composite. Nevertheless, at fourth day the amount which measuring was decreased, it might absorption iron onto the surface of composite. 


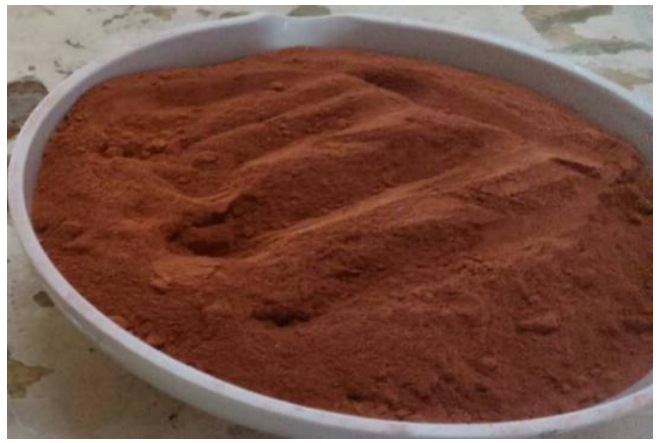

(a)

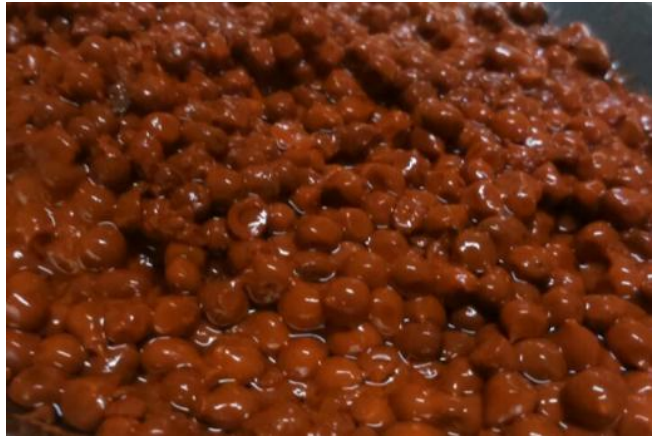

(b)

Figure 3. (a) Laterite soil from East Kotawaringin and (b) Composite Beads

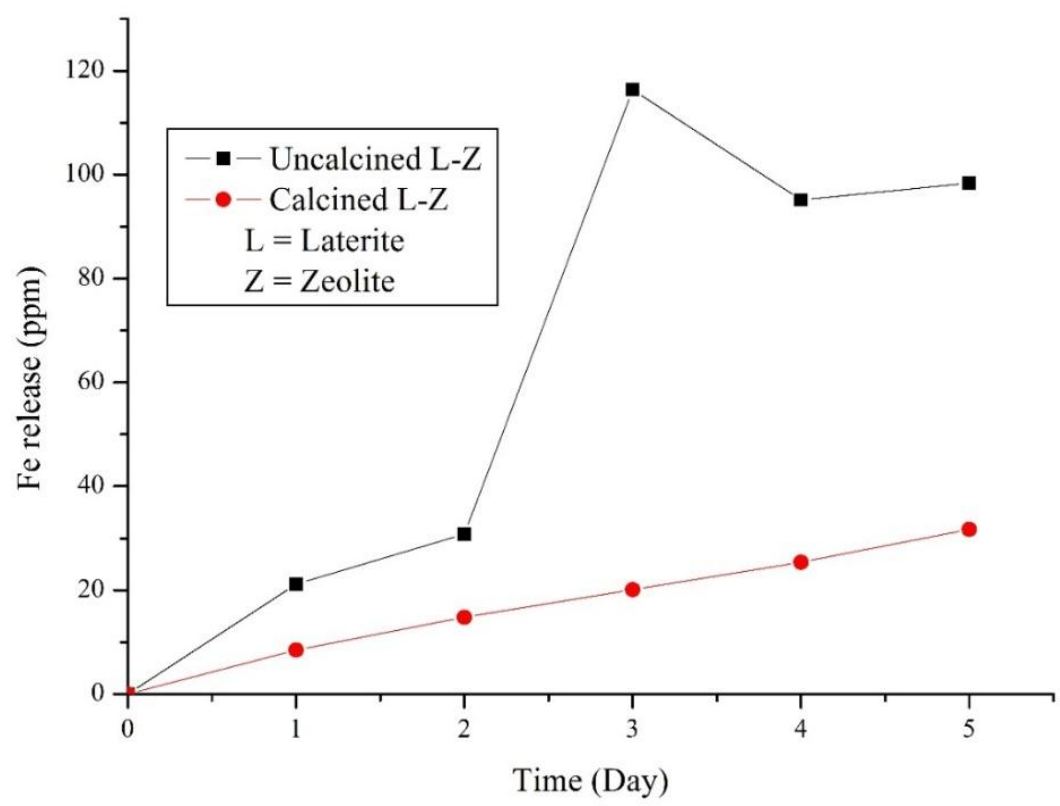

Figure 4. Effect of calcine process on Fe release

Because the release performance examine using the batch method, the higher amount of iron into the water might interact with composite if their amount too high.

The second optimation in this work is the effect of chitosan concentration, chitosan has function as polymer binder and leads to releasing of iron be slower. As explains that chitosan interacted with water and it will release the iron from composite, the higher concentration of chitosan made the releasing of iron to be faster. It caused the swelling of composite due to an interaction of chitosan and water, so the higher concentration of chitosan leads to increasing hydrophilicity properties of the composite which affects on releasing iron from composite. The higher hydrophilicity caused diffusion of water can be easier and iron would dissolve or released into water.

As can be seen in Figure 5 which represent the effect of chitosan concentration on releasing performance, the concentration chitosan $2 \%$ exhibit the slower releasing of iron, while the higher chitosan concentration leads the releasing of iron was faster. Release performance of composite from first to the third day was unconstantly amount of iron which releasing, while after third-day testing, the increasing amount of iron was constant. It is caused the composite had saturated by water molecule and it leads releasing of iron being constant.

The ratio of zeolite and laterite also affects on release performance, in this work also tested the release performance with different ratio zeolite : laterite $=2: 1,1: 1,1$ : 2. The higher amount of zeolite will decrease the rate of releasing of iron, it caused zeolite have function as support and hosting material which has porous to controlled releasing of iron. Beside polymer binder, hosting material also affected on releasing performance of iron. 


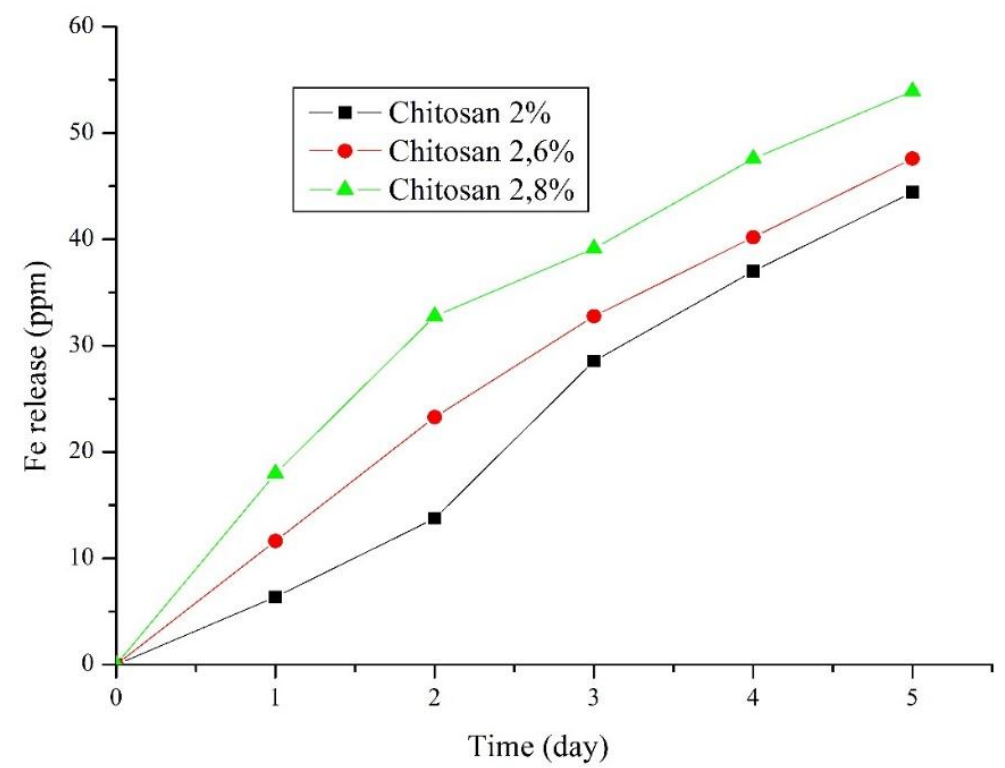

Figure 5. Effect of chitosan concentration on Fe release

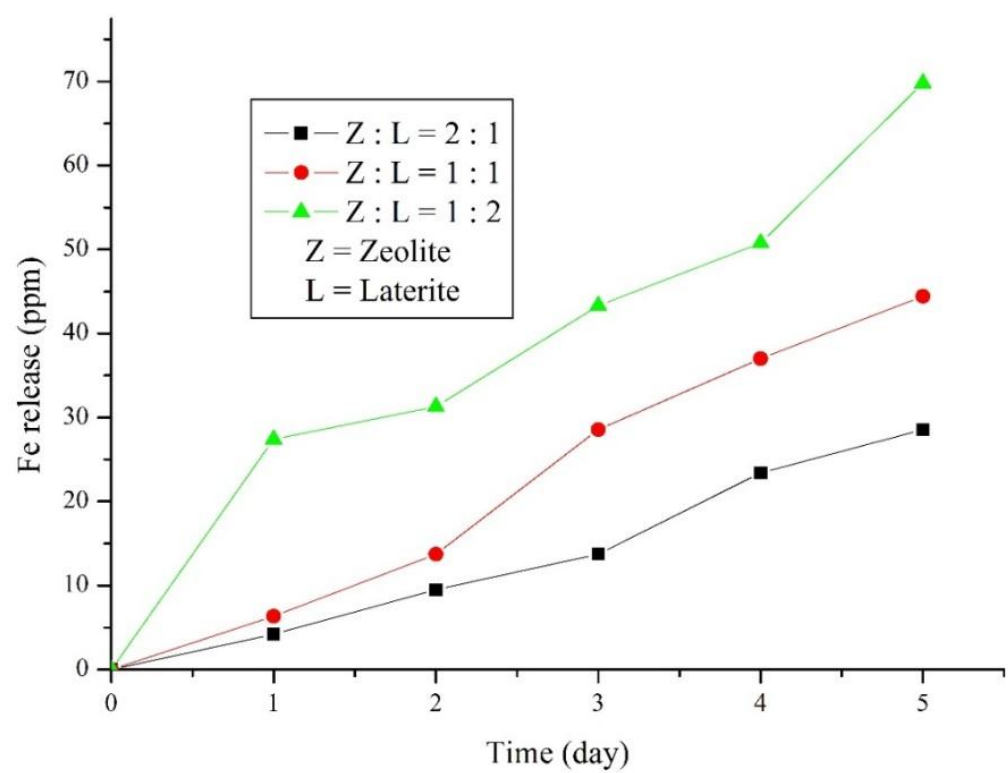

Figure 6. Effect of zeolite and laterite ratio on Fe release

While the higher amount of laterite will increase releasing performance of iron from composite due to laterite was not completely impregnated into zeolite's pore. Effect of zeolite and laterite ratio is shown in Figure 6, releasing iron from first to the fifth day has a similar trend of all ratio. The longer time of testing made increase the amount of iron. Zeolite : Laterite with 2:1 ratio has slower performance, while Zeolite : Laterite $=1: 2$ has faster-releasing performance.

\section{CONCLUSION}

The composite which formed by Laterite East Kotawaringin-Zeolite/Chitosan was success- fully synthesized as slow release of iron fertilizer. Based on XRF result, the amount of iron into laterite reach up to $80 \%$ and it is very promising as the iron source. It was supported by XRD pattern which represents that characteristic peak of goethite and hematite. Then, the performance test of slow release exhibit the higher the concentration of chitosan which is used, then more $\mathrm{Fe}$ is released from fertilizer. Whereas if the amount of zeolite is greater, the slower the release of Fe will be.

\section{ACKNOWLEDGEMENT}

We thank to "Dinas Pengelolaan Keuangan 
dan Anggaran Daerah (DPKAD)" of East Kotawaringin regency for financial support and Inorganic Chemistry's Laboratory of Brawijaya University for providing research facilities.

\section{REFERENCES}

Azeem, B., Kushaari, K., Man, Z. B., Basit, A., \& Thanh, T. H. (2014). Review on materials \& methods to produce controlled release coated urea fertilizer. Journal of Controlled Release, 181(1), $11-21$.

Cairo, P. C., Armas, J. M. De, Artiles, P. T., Martin, B. D., Carrazana, R. J., \& Lopez, O. R. (2017). Effects of zeolite and organic fertilizers on soil quality and yield of sugarcane. Australian Journal of Crop Science, 11(06), 733-738.

Hartanto, D., Iqbal, R. M., Fansuri, H., Iryani, A., Shahbihi, W. E., \& Santoso, E. (2017). Effect of $\mathrm{H}_{2} \mathrm{O} / \mathrm{SiO}_{2}$ molar ratio on direct synthesis of ZSM-5 from Bangka's kaolin without pretreatment. Malaysian Journal of Fundamental and Applied Sciences, 13(4), 817-820.

Iqbal, R. M., Nurherdiana, S. D., Hartanto, D., Othman, M. H. D., \& Fansuri, H. (2018). Morphological control of $\mathrm{La}_{0.7} \mathrm{Sr}_{0.3} \mathrm{Co}_{0.2} \mathrm{Fe} \quad{ }_{0.8} \mathrm{O}_{3-\delta} \quad$ and $\mathrm{La}_{0.7} \mathrm{Sr}_{0.3} \mathrm{MnO}_{3-\delta}$ catalytic membrane using $\mathrm{PEG}-\mathrm{H}_{2} \mathrm{O}$ additive. In IOP Conference Series: Materials Science and Engineering, (Vol. 348, p. 012008). IOP Publishing

Jozwiak, W. K., Kaczmarek, E., Maniecki, T. P., Ignaczak, W., \& Maniukiewicz, W. (2007). Reduction behavior of iron oxides in hydrogen and carbon monoxide atmospheres. Applied Catalysis A: General, 326(1), 17-27.

Koinuma, H., \& Takeuchi, I. (2004). Combinatorial solid-state chemistry of inorganic materials. Nature Materials, $3(7), 429-438$.

Kottegoda, N., Munaweera, I., Madusanka, N., \& Karunaratne, V. (2011). A green slow-release fertilizer composition based on urea-modified hydroxyapatite nanoparticles encapsulated wood. Current Science, 101(1), 73-78.

Mandal, S., \& Axel, H. E. M. (2008). Facile route to the synthesis of porous $-\mathrm{Fe}_{2} \mathrm{O}_{3}$ nanorods, $111(13)$, 438-443.

Phuc, D. H., Hiep, N. T., Chau, D. N. P., Hoai, N. T. T., Khon, H. C., Toi, V. Van, Bao, B. C. (2016). Fabrication of Hyaluronan-Poly(vinylphosphonic acid)Chitosan Hydrogel for Wound Healing Application. International Journal of Polymer Science, 2016.

Piluharto, B., Suendo, V., \& Maulida, I. (2017). Composite Beads Of Chitosan/Bentonite As A Matrix For Phosphate Fertilizer Controlled-Release. Journal of Chemical Technology and Metallurgy, 52, 1027-1031.

Prasetiyo, P. (2008). Utilizing Indonesia's Nickel Ore Potential in the Present and Future. Metalurgi, 23(I).

Rashidzadeh, A., Olad, A., Salari, D., \& Reyhanitabar, A. (2014). On the preparation and swelling properties of hydrogel nanocomposite based on Sodium alginate- $\mathrm{g}$-Poly ( acrylic acidco -acrylamide )/ Clinoptilolite and its application as slow release fertilizer. Journal Polymer Resource, 21, 344.

Wardhani, S., Rahman, M. F., Purwonugroho, D., \& Tjahjanto, R. T. (2016). Photocatalytic Degradation of Methylene Blue Using $\mathrm{TiO}_{2}$ - Natural Zeolite as A Photocatalyst. Journal Pure and Applied Chemistry Research, 5, 1926.

Yao, Y., Gao, B., Chen, J., \& Yang, L. (2013). Engineered Biochar Reclaiming Phosphate from Aqueous Solutions: Mechanisms and Potential Application as a Slow-Release Fertilizer. Environmental Science and Technology, 47, 8700-8708. 